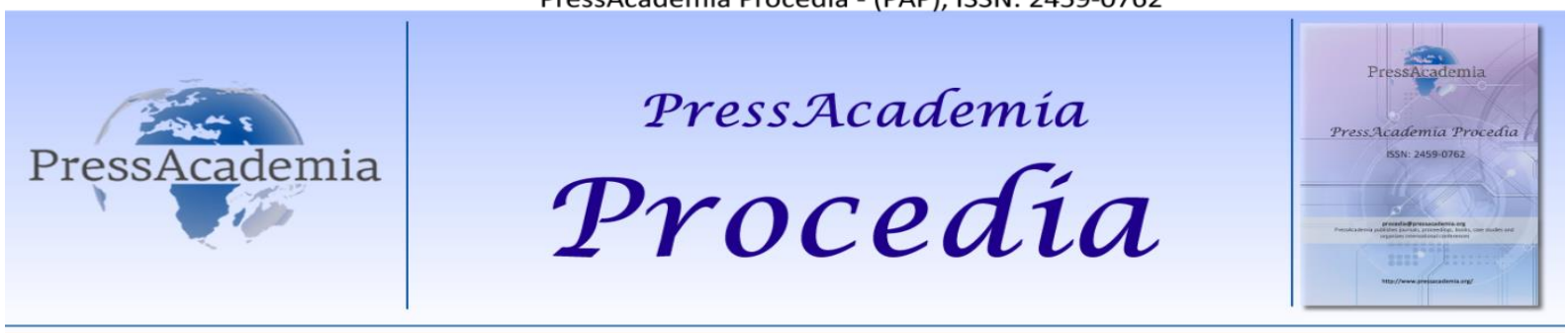

Global Business Research Congress (GBRC), May 24-25, 2017, Istanbul, Turkey

\title{
THE INVESTIGATION OF THE DEMOGRAPHIC FACTORS OF THE ETNOCENTRIC TENDENCY LEVELS OF TURKISH CONSUMERS IN THE CONTEXT OF THE CULTURAL EFFECTS OF GLOBALIZATION
}

DOI: 10.17261/Pressacademia.2017.635

PAP- GBRC-V.3-2017(61)-p.590-598

\author{
Husniye Ors ${ }^{1}$, Ozlem Catli ${ }^{2}$, Aysegul Ermec Sertoglu ${ }^{3}$ \\ ${ }^{1}$ Gazi Üniversitesi, iktisadi ve İdari Bilimler Fakültesi, Ankara, Türkiye. husniye@gazi.edu.tr \\ ${ }^{2}$ Gazi Üniversitesi, îktisadi ve İdari Bilimler Fakültesi, Ankara, Türkiye. ozlembarel@gazi.edu.tr \\ ${ }^{3}$ Gazi Üniversitesi, İktisadi ve İdari Bilimler Fakültesi, Ankara, Türkiye. aermec@gazi.edu.tr
}

\section{To cite this document}

Ors, H., Catli, O., Sertoglu, A, (2017). The investigation of the demographic factors of the etnocentric tendency levels of Turkish consumers in the context of the cultural effects of globalization. PressAcademia Procedia (PAP), V.3, p.590-598.

Permemant link to this document: http://doi.org/10.17261/Pressacademia.2017.635

Copyright: Published by PressAcademia and limited licenced re-use rights only.

\begin{abstract}
Given the fact that globalization is an influencing factor shaping all structures of society, it is the testing of three theses with consumer ethnocentrism that is defined in terms of its cultural effects and, additionally, the examination of consumer ethnocentrism in terms of demographic factors. As a descriptive research, it was carried out through a face-to-face survey method and easy sampling and conducted on 230 respondents. A 17-unit CETSCALE scale was used to measure the ethnocentric levels of consumers, and the measurement was found to be reliable. As a result of the analyzes made, it was found that the ethnocentric tendency levels of the Turkish consumers were moderate, that it did not change according to age or gender and that those with higher education levels showed a lower ethnocentric tendency. The research concluded that the 'hybridization' thesis was acceptable from possible theses regarding the cultural effects of globalization.
\end{abstract}

Keywords: Globalization, culture, ethnocentrism, consumer behavior, marketing JEL Codes: M30, M31, Z1

\section{KÜRESELLEŞMENIN KÜLTÜREL ETKISI BAĞLAMINDA TÜRK TÜKETICILERIN ETNOSENTRIK EĞiLIM DÜZEYLERININ DEMOGRAFIK FAKTÖRLER ITIBARIYLE INCELENMESI}

\section{ÖZET}

Küreselleşmenin toplumun tüm yapılarını şekillendiren bir etki faktörü olması gerçeği ile kültürel etkilerine ilişkin tanımlanan üç tezin tüketici etnosentrizmi ile sınanması, ayrıca tüketici etnosentrizminin demografik faktörler itibariyle incelenmesidir. Tanımlayıcı bir nitelik taşıyan araştırma, yüz yüze anket yöntemi ve kolayda örnekleme ile 230 cevaplayıcı üzerinde yapılmıştır. Tüketicilerin etnosentrik düzeylerini ölçmek için 17-birimlik CETSCALE ölçeği kullanılmış olup, ölçüm güvenilir bulunmuştur. Yapılan analizler sonucunda Türk tüketicilerin etnosentrik eğilim düzeylerinin orta düzeyde olduğu, yaş ve cinsiyete göre değişmediği, eğitim düzeyi yüksek olanların daha düşük düzeyde etnosentrik eğilim gösterdiği ortaya konmuştur. Araştırma ile küreselleşmenin kültürel etkilerine ilişkin olası tezlerden 'hibritleşme' tezinin kabul edilebilir olduğu sonucu elde edilmiştir.

Anahtar Kelimeler: Küreselleşme, kültür, tüketici etnosentrizmi, tüketici davranışları, pazarlama JEL Kodları: M30, M31, Z1 


\section{GíRiş}

Küreselleşme sosyal bilimler alanında son yıllarda çok yoğun olarak araştırılan konular arasında yer almış ve yer almaya devam etmektedir. Küreselleşmenin kültüre olan etkilerini inceleyen yazında, diğer tezlerin yanı sıra küreselleşmenin kültürü homojenleştirdiği tezi daha yüksek düzeyde destek görmektedir. Bu tezin tüketim yaklaşımına göre, tüketicilerin ihtiyaçları küresel ürünler aracılığı ile karşılanmaktadır. Tüketici etnosentrizmi; tüketicilerin yerli ürünler dışındaki ürünleri kullanmanın ve satın almanın uygunluğunu ve ahlaki olup olmamasını sorgular; yerli ürün alınmasını destekler ve bu ürünlere yabancı menşeli ürünlerden daha fazla değer atfeder. Bu tüketicilerin en belirgin özellikleri; yabancı ürün satın almanın yanlış olduğuna, bu durumun ülke ekonomisine zarar verdiğine ve işsizliğe açtığına olan inançlarıdır.

\section{LITERATURE INCELEMESi}

\subsection{Küreselleşme ve Kültürel Etkileri}

Küreselleşme, özellikle teknolojik gelişmelerle beraber bilginin, insanın, sermayenin, fikirlerin sınır tanımadan serbestçe dolaşır hale gelmesine zemin hazırlamış, ticarette 'coğrafik alan'a olan ihtiyacı ortadan kaldırarak tüketicilerin bir 'dünya tüketicisi' olması sonucunu doğurmuştur ( Harvey, 1992; McNeill, 1986). Yaşadığımız dönemde küreselleşmede gelinen son durum; dünyanın çeşitli parçaları arasında karşıııklı-bağımlılık ve yeni şekilde bütünleşmede; 'zaman-mekan sıkışması' olarak kavramlaştııılmış ve böylece 'zamanın mekandan bağımsızlaşması', küreselleşmenin ön koşulu (Giddens, 1998:66) haline gelmiştir. 21. yüzyılda, özellikle iletişim teknolojilerindeki gelişmeler sayesinde bir 'küresel kültür'ün doğduğu varsayımları sosyal bilimlerde yaygın kabul haline gelmiş olup, küreselleşmenin kültürel etkileri üzerine tezler geliştirilmiş ve geliştirilmeye devam edilmektedir. Konu ile ilgili literatürde üç-olası tez tanımlanmıştır. Bunlar; homojenleşme tezi, kutuplaşma tezi ve hibritleşme tezidir ( Holton, 2013:63).

- Homojenleşme Tezi: Bu teze göre küreselleşme; kültürel özellikler ile pratik uygulamaları birbirine yaklaştırmış ve kültürü homojenleştirmiştir (Giddens, 1998:66). Kültürün homojenleşmesi; 'Amerikanlaşma' anlamına gelmekte, küresel tüketim yalnızca ürünlerin bir ihtiyaca cevap vermesine bağıı olmamakta aynı zamanda Hollywood endüstrisi ile zenginlik rüyaları, kişisel başarı ve hedonizm-temelli ürünlerin de sunulması ile Amerikan ve Batı kültürü diğer ülkelere transfer edilmektedir.

-Kutuplaşma Tezi: Bu tezin savunucularının temel aldığı dayanak; medeniyetler çatışmasıdır. Buna göre küreselleşme ile etnik temizlik, ulusalcılık ve nefrete dayalı politik kimlikler meydana gelmiş ve bu medeniyetler zıt-iki kutupta (Keyman, 1998) kümelenmiştir; batının Orta Doğu İslam coğrafyasını statik, otoriter, 'şark' olarak; batıyı ise akılcı, hoşgörülü, yenilikçi ve dinamik olarak gördüğ̈ iki kutup olarak.

-Hibritleşme Tezi: Bu tezin savunucularına göre günümüzde kültürler yüksek düzeyde birbirine girmiş ve karışmış olduğundan, saf, otantikbir kültürden bahsetmenin mümkün olamaz ( Hannerz, 1998).Robertson'a ( 1998) göre küreselleşme ile farklı kültürler farklı derecelerde biribirleri ile etkileşime girmekte ve bunun sonucu küresel kültür kendini kısmen ulusal kültür ile ve küresel etkileşimlerin özgünlüğü ile yapılanmaktadır.

\subsection{Tüketici Etnosentrizmi}

Sosyoloji yazınında William G.Summer tarafından kavramlaştırılan etnosentrizm; bireyin, kendisini onun bir üyesi olarak kabul ettiği etnik grubu her şeyin merkezi olarak görmesi, toplumdaki diğer sosyal grupları üyesi olarak algıladığı grup perspektifinden değerlendirmesi, kendi kültürüne benzemeyenleri ret etmesi (Shimp, Sharma, 1987: 280). Entnosentrizm eğilimli bireylerin üyesi oldukları etnik grubu yaşam alanlarının merkezine koymaları; kendi kültür özellikleri ile gurur duyma ve diğer grupların kültür özelliklerini hor görme (Netemeyer, Durvasula, Linhtenstein, 1991) sonucunu beraberinde getirmektedir. Sosyoloji alanında, özellikle kültüre ilişkin çalışmalarda yüksek düzeyde çalışılan kavram diğer sosyal disiplinlerin yanı sıra pazarlama alanında da yaygın olarak araştırılmaktadır. Etnosentrizm kavramı pazarlama yazınına 'tüketici etnosentrizmi' ifadesiyle, 1987 yılında Shimp ve Sharma tarafından kazandırılmıştır. Tüketici etnosentrizmi; Pazar bölümlendirme, ürün/marka konumlandırma, ürün/hizmet kalite iyileştirme, sosyal sorumluluk projelerine temel oluşturma gibi birçok yönetsel pazarlama alanlarında kullanılmaktadır. Tüketici etnosentrizmi; pazarlama yöneticilerinin hedef pazarlarındaki tüketicilerin yabancı ve yerli ürünlere ilişkin ön yargı ve ön kabullerini anlayabilmelerini sağlayarak en uygun pazarlama stratejilerini geliştirmelerine katkı (Cataora, 2000) sağlamakta ve pazar bölümlendirme faktörü olarak (Kaynak, Kaya, 2002) işlev görmektedir. Tüketici etnosentrizmi; grup içindeki kabullere etki ettiğinden grup üyesi olan bireyin kişiliğine yön verir ki bu etki kendini satın alma davranışında da göstererek kabul edilen veya edilmeyen satın alma davranışının 'hangisi' olduğunun anlaşımasını sağlar (Shimp, Sharma, 1987), grup üyesinin yabancı menşeli ürünleri satın alma ve kullanmanın ne derece etik olup olmadığını gösterir. Yapılan araştırmalar, yerli ürün tercih etme ile pozitif yönde (Balabanis, Diamantopoulis, 2004), yabancı ürün tercih etme ile negatif yönde (Klein, Ettenson, Morris, 1998) ilişki olduğunu, etnosentrik eğilimi yüksek tüketicilerin düşük olanlara göre kendi ülkesinin ürünlere daha yüksek değer 
atfettiklerini, yabancı ürün satın almanın yanlış olduğuna inandıklarını, yabancı ürün satın almanın ülke ekonomisine olumsuz etki ettiği ve işsizliğe yol açtığına inandıklarını, vatanseverlikle ters düştüğü inancını taşıdıklarını, bu nedenle ülke ve milletini seven bireylerin yerli ürün satın almaları gerektiğini düşündüklerini (Balabanis, Diamantopoulos, 2004; Shimp, Sharma, 1987; Shankarmahesh, 2006), yabancı ürün sarın almanın kabul edilmeyen bir siyasi davranış olduğunu (Altındaş, Tokol, 2007) ortaya koymuştur.

Tüketici davranışları yazınında etnosentrizm ile ilgili araştırmaların ortaya koyduğu sonuçların dikkat çekici tarafı; gelişmiş ülke vatandaşlarının kendi ülkelerinde üretilen ürünlerin daha iyi olduğuna olan inançlarından dolayı yerli ürünü tercih ettikleri (Klein, Ettenson, Morris, 1998), bunun aksine gelişmekte olan ülke vatandaşlarının ekonomisi daha gelişmiş ülke menşeli ürünlerin daha iyi olduğuna ve yerel ürünün kalitesinin düşük olduğuna ilişkin yargılarından dolayı yabancı ürün tercih ettikleri (Wang, Chen, 2004) bulgularıdır. Bu araştırma bulgularının tüketicilerin etnosentrik davranışlarında rasyonel kriterleri de dikkate aldıklarını ortaya koyduğunu gösterdiği ifade edilebilir. Dolaysıyla tüketici etnosentrizmi kavramı sosyal bilimlerde stratejik önemini korumakla beraber, ekonomik avantaj yaratması durumuna bağlı olarak davranışa yön verdiği bulgusu ile paradoksal bir kabule sahip olduğu düşünülebilir.

\section{VERI VE YÖNTEM}

\subsection{Araştırmanın Amacı}

Literatür taramasına istinaden, küreselleşmenin kültürel homojenlik yarattığı görüşü doğru kabul edildiğinde, bunun tüketim kültürüne de yansıması beklenilir. Bunun sonucu olarak ülkeler bazında tüketici etnosentrizm düzeyinin düşük çıkması beklenir. Bu bağlamda araştırmanın amacı; Türk tüketicilerinin etnosentrik düzeylerini belirlemek ve demografik faktörler itibariyle incelemek ve elde edilen sonuçların küreselleşmenin kültüre etkileri bağlamında kültürün homojenleşmesi tezinin sınanmasına katkı sağlamaktır. Bu yönü ile araştırma tanımlayıcıbir özellik taşımaktadır.

\subsection{Araştırma Düzeni}

Araştırmada küreselleşmenin kültürel etkilerinden sosyoloji yazınında çalışılan üç tez dikkate alınmıştır. Toplumlardaki kültürel yapı, o toplumda yaşayan bireylerin kültür kodlarını oluşturur ve bu kodlar sosyal ve ekonomik yapılarda davranışlar olarak kendini ifadeler. Araştırmada küreselleşmenin kültürel etkilerini, toplum bireylerinin tüketim davranışlarından etnosentrik eğilimlerini inceleyerek ortaya koymak hedeflenmiş ve araştırma amacı doğrultusunda belirlenen hedeflere ulaştıracak araştırma düzeni Şekil 1'de gösterilmiştir.

\section{Şekil 1: Araştırma Düzeni}

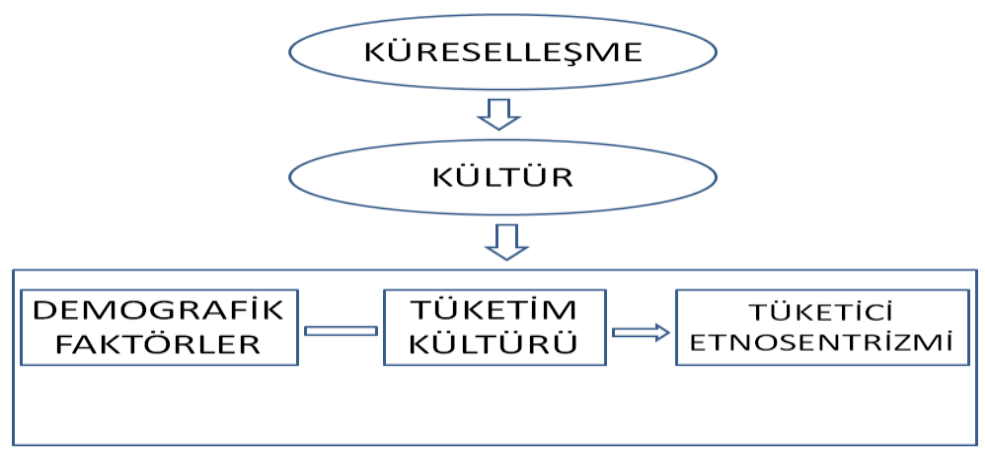

Yukarıda açıklanan kavramsal çerçeve ve bilimsel yazına istinaden, test edilecek tezler aşağıda belirtilmiştir.

\section{Tez 1:}

Homojenlik tezine göre küreselleşme kültür homojenliği yaratmış ve tüm kültürleri 'Batı́lılaşma/Amerakınlılaşma' şeklinde etkilemiştir. Bu tez doğru kabul edilirse, Türk tüketicilerinin etnosentrik eğilim düzeylerinin 'düşük' çıkması beklenir. Bu teze ilişkin sınama, aşağıda gösterildiği şekilde formüle edilmiştir.

$$
\text { Homojenlik Tezi Doğru }
$$

Türk Tüketicisinin Etnosentrik Düzeyi Düşük 


\section{Tez 2:}

Kutuplaşma tezine göre küreselleşme kültür kutuplaşması yaratmış ve tüm toplumlar 'İslam/Doğu Kültürü' ile 'Batı/Amerikan Kültürü' şeklinde iki kupta ayrılmıştır. Bu teze göre Türk tüketicilerinin 'Doğu Kültürü' kategorisinde olması gerekir. Bu tez kabul edilirse, Türk tüketicilerinin etnosentrik eğilim düzeylerinin 'yüksek' çıkması beklenir. Bu teze ilişkin sınama, aşağıda gösterildiği şekilde formüle edilmiştir.

$$
\text { Kutuplaşma Tezi Doğru }
$$

Türk Tüketicisinin Etnosentrik Düzeyi Yüksek

Tez 3:

Hibritleşme tezine göre saf bir kültürden bahsedilemez ve küreselleşme ile farklı kültürler farklı düzeylerde birbirlerini etkilemektedirler. Türk tüketicilerinin etnosentrik eğilim düzeylerinin 'orta' çıkması beklenir. Bu teze ilişkin sınama, aşağıda gösterildiği şekilde formüle edilmiştir.

\section{Hibritleşme Tezi Doğru Türk Tüketicisinin Etnosentrik Düzeyi Orta}

Araştırma amacında belirtildiği üzere, Türk tüketicilerin etnosentrik eğilim düzeylerinin demografik faktörler itibariyle ortaya koyabilmek için aşağıdaki hipotezler oluşturulmuştur:

$\mathrm{H}_{1}$ : Tüketicilerin etnosentrik düzeyleri, cinsiyete göre farklılık gösterir.

$\mathrm{H}_{2}$ : Tüketicilerin etnosentrik düzeyleri, yaşa göre farklılık gösterir.

$\mathrm{H}_{3}$ : Tüketicilerin etnosentrik düzeyleri, eğitime göre farklılık gösterir.

\section{3. Örneklem}

Araştırmada küreselleşmenin kültürel etkilerine ilişkin sosyoloji yazınında ortaya atılan üç tezin tüketim kültürü üzerinden tüketici etnosentrizmi ile sınanması amaçlanmış olduğundan, araştırma birimi Türk tüketicileri olarak tanımlanmıştır. Ana kütlenin çok geniş olması dolayısıyla örnekleme yapılmıştır. Bunun için Ankara ili merkez ilçesinde kolayda örnekleme yöntemine karar verilmiştir.

\subsection{Veri Toplama ve Ölçme Araçları}

Araştırmada veriler anket yöntemi ile toplanmıştır. Bunun için Sosyal Bilimler Enstitüsü Yüksek Lisans öğrencilerinden araştırma metodolojisi eğitimi ve anket uygulaması deneyimine sahip 8 öğrenciye, araştırmacılar tarafından araştırma ve anket ile ilgili detaylı açıklama yapılmıştır. Anket uygulaması tüketim ehliyeti dikkate alınarak 15 yaş üstünde olanlar üzerinde, Ankara ili merkez ilçesinde yapılmıştır. Bunun için coğrafik olarak birbirinden uzak üç adet AVM seçilmiş ve bir hafta içi ve bir hafta sonu, aynı haftada iki gün olarak yüz yüze uygulanmıştır. Saha araştırması sonucu 230 tüketiciden veri toplanmıştır.

Anket iki bölümden oluşmuştur. Birinci bölüm demografik faktörlerden yaş, cinsiyet ve eğitim değişkenlerine ilişkin soruları içermiştir. i̇kinci bölümde tüketicilerin etnosentrik düzeylerini ölçmeye yönelik 17-birimlik CETSCALE ölçeği yer almıştır. Orijinali 7'liLikert olan ölçek aşırı hassas olduğundan ve önceki deneyimlerden hareketle, Türk tüketicilerin bu hassasiyet farkını ortaya koymakta isteksiz olduklarından ölçek 5'liLikert olarak düzenlenmiştir. CETSCALE ölçeğinin orjinali İngilizcedir. Ölçek Türkiye'de oldukça sık kullanılmış olduğundan, daha önceki araştırmalarda yapılan (Örs, Yılmaz, Doğan, 2016: 27) Türkçe çevirisinin kullanılması uygun görülmüştür. Araştırma hipotez analizleri SPSS.23 kullanılarak yapılmıştır.

\section{BULGULAR VE TARTIŞMA}

Araştırmaya katılan cevaplayıcılara ilişkin tanımlayıcı istatistikler Tablo 1'de gösterilmiştir. Tablo 1'de görüldüğü üzere cevaplayıcıların \%46.5'i kadın, \%53.5'i erkek tüketicilerden oluşmaktadır. Yaş değişkeni incelendiğinde; cevaplayıcıların \% 8,3'ü 18 altı, \%63,9'u 18-25 yaş arası, \%27,8'i 26-44 yaş arasında olup, 45 yaş üstü olan cevaplayıcı olmamıştır. Eğitim değişkenine ilişkin dağııım ise cevaplayıcıların \%4.8'i illköğretim, \%61,7'si Lise ve \%33,5'i üniversite mezunu şeklindedir. Eğitime ilişkin 'Okumamış' grubuna giren cevaplayıcı çıkmamıştır. 
Tablo 1: Katılımcıların Demografik Özellikleri

\begin{tabular}{|c|c|c|c|}
\hline & & $\mathrm{F}$ & $\%$ \\
\hline Cinsivet & Kadın & 107 & 46,5 \\
\hline Cinsiyet & Erkek & 123 & 53,5 \\
\hline & $15-18$ & 19 & 8,3 \\
\hline & $18-25$ & 147 & 63,9 \\
\hline Yas & $26-34$ & 32 & 13,9 \\
\hline raş & $35-44$ & 32 & 13,9 \\
\hline & $45-54$ & 0 & 0 \\
\hline & $55-64$ & 0 & 0 \\
\hline & İlköğretim & 11 & 4,8 \\
\hline Egitim & Lise & 142 & 61,7 \\
\hline & Üniversite & 77 & 33,5 \\
\hline Toplam & & 230 & 100 \\
\hline
\end{tabular}

Katılımcılardan Tüketici Etnosentrizmi ölçeğinde yer alan ifadelere katılma düzeyleri Tablo 2'de sunulmuştur. Buna göre CETSCALE ölçeğindeki 17 ifadeden en düşük olan ifadeler 2,16 düzey ile 'Yabancı ülke ürünlerini satın almak Türklüğe aykırıdır' ve 2,25 düzey ile 'Tüm ithal ürünlere engel konmalıdır', en yüksek ifade ise 4,01 düzey ile 'Türk yapımı ürünler satın almak, Türkiye çalışanını korur' ve 3,50 düzey ile 'Sadece Türkiye'de bulunmayan ürünler ithal edilmelidir' ifadeleridir. Ölçek birimlerine ilişkin düzeyler incelendiğinde, Türk tüketicilerin etnik kimlikten çok ülkenin ekonomik avantajını dikkate alarak tüketim davranışını sergilediği söylenebilir.

Tablo 2: Tüketici Etnosentrizmi Ölçeğine İlişkin Temel İstatistiksel Göstergeler

\begin{tabular}{|c|c|c|c|c|c|}
\hline & & Ortalama & Std. Sapma & Çarpıklık & Basıklık \\
\hline 1 & Türk halkı her zaman ithal ürünler yerine Türk yapımı ürünler satın almalıdır. & 3,3739 & 1,28111 &,- 200 &,- 977 \\
\hline 2 & Sadece Türkiye'de bulunamayan ürünler ithal edilmelidir. & 3,5000 & 1,33069 &,- 415 & $-1,020$ \\
\hline 3 & Türk yapımı ürünler satın almak, Türkiye çalışanını korur & 4,0130 & 1,07566 & $-1,152$ & ,757 \\
\hline 4 & Türk yapımı ürünler her şeyden önce gelir. & 3,3826 & 1,29549 &,- 353 &,- 891 \\
\hline 5 & Yabancı ülke ürünlerini satın almak Türklüğe aykırıdır. & 2,1696 & 1,36453 & ,907 &,- 505 \\
\hline 6 & Yabancı ürünler satın almak doğru değildir, çünkü Türklerin işsiz kalmasına neden olur & 2,7348 & 1,32629 & ,351 &,- 952 \\
\hline 7 & Gerçek bir Türk, her zaman Türk yapımı ürünler satın almalıdır. & 2,6435 & 1,43683 & , 368 & $-1,172$ \\
\hline 8 & $\begin{array}{l}\text { Diğer ülkelerin bizim üzerimizden zengin olmasına müsaade etmek yerine Türkiye'de üretilmiş } \\
\text { ürünler satın almalıyız. }\end{array}$ & 3,3348 & 1,31704 &,- 325 &,- 956 \\
\hline 9 & Her zaman Türk ürünlerini satın almak en iyidir. & 3,1000 & 1,34245 &,- 053 & $-1,094$ \\
\hline 10 & Zorunlu haller dışında, diğer ülkelerden mal satın alımı veya ticareti çok az olmalıdır. & 3,2348 & 1,34671 &,- 198 & $-1,098$ \\
\hline 11 & $\begin{array}{l}\text { Türk işletmelerine zarar verdiği ve işsizliğe neden olduğu için Türkler yabancı ürünleri satın } \\
\text { almamalıdır. }\end{array}$ & 2,8870 & 1,31345 & ,106 & $-1,021$ \\
\hline 12 & Tüm ithal ürünlere engel konulmalıdır. & 2,2522 & 1,37249 & ,794 &,- 626 \\
\hline 13 & Uzun dönemde maliyetli de olsa, Türk ürünlerini desteklemeyi tercih ederim. & 3,2913 & 1,27708 &,- 320 &,- 887 \\
\hline 14 & Yabancıların pazarlarımıza ürünlerini sokmalarına izin verilmemelidir. & 2,4043 & 1,36934 & ,609 &,- 799 \\
\hline 15 & Türkiye'ye girişinin azaltılması için yabancı ürünler yüksek oranda vergilendirilmelidir. & 2,8739 & 1,38511 & 069 & $-1,210$ \\
\hline 16 & Sadece kendi ülkemizde bulamadığımız ürünleri yabancı ülkelerden satın almalıyız. & 3,3174 & 1,33778 &,- 399 & $-1,022$ \\
\hline 17 & $\begin{array}{l}\text { Diğer ülkelerde üretilen ürünleri satın alan Türk tüketicileri, vatandaşları olan Türk halkının } \\
\text { işsizliğine neden olmakla sorumludurlar. }\end{array}$ & 2,6130 & 1,38072 & ,390 & $-1,068$ \\
\hline
\end{tabular}

Araştırmanın ölçümünün güvenilirliğini test etmeden önce, faktör sayısı 1 olacak şekilde kısıtlama yapılarak Keşifsel Faktör Analizi gerçekleştirilmiş, elde edilen faktör yükleri Tablo 3'te sunulmuştur. 
Tablo 3: Tüketici Etnosentrizmi Ölçeği Tek Boyutluluk Analizi

\begin{tabular}{|c|c|}
\hline & Faktör1 \\
\hline İfade 17 & ,826 \\
\hline Ifade 9 & ,821 \\
\hline Ifade 8 & ,807 \\
\hline Ifade 7 &, 805 \\
\hline ifade 11 & ,792 \\
\hline Ifade 6 & ,766 \\
\hline ifade 10 & ,745 \\
\hline Ifade 14 & ,717 \\
\hline Ifade 13 & ,713 \\
\hline Ifade 5 & ,709 \\
\hline Ifade 15 & ,698 \\
\hline Ifade 16 &, 672 \\
\hline ifade 4 & ,664 \\
\hline Ifade 12 &, 659 \\
\hline ifade 1 &, 596 \\
\hline Ifade 2 &, 546 \\
\hline Ifade 3 & ,489 \\
\hline
\end{tabular}

KMO Measure of Sampling Adequacy $=, 926$ Bartlett's Test of Sphericity Approx. Chi-Square $=2603,943$ sign $=0,000$

Tablo 3'te görüldüğü gibi tek faktör altında toplanması sağlanan ifadelerin faktör yükleri 0,45'in üzerindedir. Ölçekteki 17 ifade ile yapılan ölçüm için hesaplanan Cronbach Alpha katsayısının 0,94, ifadelerin düzeltilmiş madde toplam puan korelasyon değerlerinin de 0,35 'in üzerinde olduğu hesaplanmıştır (Bearden, Hadesty, Rose, 2001). Buna göre ölçeğin güvenilir olduğu söylenebilir. Araştırma amacı dikkate alınarak, Türk tüketicilerin etnosentrik eğilim düzeyleri hesaplanmış ve ortalama bir skor elde edilmiştir. Buna göre katılımcıların Etnosentrik eğilimleri Tablo 4'de görüldüğü üzere, 'orta' düzeyde gerçekleşmiştir ( $\bar{X}=3,007$ ve CETSCORE= 51,12). Bu sonuç, Türkiye'de gerçekleştirilen bazı araştırma bulgularından ( Yapraklı ve Keser, 2013; Çilingir, 2014) farklılık göstermekle beraber,daha büyük bir oranla ise bazı araştırma bulguları (Turgut, 2010; Asil, Kaya, 2013; Uyar ve Dursun, 2015; Arı ve Madran, 2011; Armağan ve Gürsoy, 2011; Akın, Çiçek, Gürbüz ve İnal, 2009; İ̧̧ler, 2013 ) ile benzerlik göstermektedir.

Tablo 4: Türk Tüketicilerin Etosentrik Eğilim Düzeyleri

\begin{tabular}{|l|c|c|}
\hline \multicolumn{1}{|c|}{ Skor Aralığı } & Sıklık (f) & Yüzde (\%) \\
\hline 17-42 (Düšük Etnosentrizm) & 79 & 34,3 \\
\hline 43-59 (Orta Etnosentrizm) & 76 & 33,0 \\
\hline 60-85 (Yüksek Etnosentrizm) & 75 & 32,6 \\
\hline Toplam & 230 & 100,0 \\
\hline
\end{tabular}

Araştırma amacına ulaşmak amacıyla oluşturulan hipotezler, \%95 güven aralığında, t-test ve varyans analizleri ile test edilmiştir. 'Tüketicilerin Etnosentrizm düzeyleri, cinsiyete göre farklıılı gösterir' şeklinde ifade edilen $\mathrm{H}_{1}$ sonuçları Tablo 5 'te gösterilmiş olup, hipotez ret edilmiştir.

\section{Tablo 5: Tüketici Etnosentrizm Düzeyleri ile Cinsiyet Faktörlerine illişkin t-Testi Sonuçları}

\begin{tabular}{|l|l|r|r|r|r|}
\hline & Cinsiyet & $\mathrm{N}$ & Ortalama & t-değeri & Anlamlıık \\
\hline $\begin{array}{l}\text { Etnosentrizm } \\
\text { düzeyi }\end{array}$ & Erkek & 123 & 3,0531 & \multirow{2}{*}{, 786} & \multirow{2}{*}{, 432} \\
\cline { 2 - 4 } & Kadın & 107 & 2,9549 & & \\
\hline
\end{tabular}

'Tüketicilerin Etnosentrizm düzeyleri, yaşlarına göre farklıık gösterir' şeklinde ifade edilen son $\mathrm{H}_{2}$ sonuçları Tablo 6 'da gösterilmiştir. Tablo $6^{\prime}$ da görüleceği üzere, tüketici etnosentrik eğilim düzeyleri yaş grupları arasında istatistiksel olarak bir fark bulunmamış ve hipotez ret edilmiştir. 
Tablo 6: Tüketici Etnosentrizm Düzeyleri İle Yaş Faktörlerine iliş̧in Varyans Analizi Sonuçları

\begin{tabular}{|l|c|c|c|c|}
\hline & $N$ & Ortalama & F-değeri & Anlamlılık \\
\hline 18 yaş altı & 19 & 2,9783 & & \\
\cline { 1 - 3 } $18-25$ & 147 & 2,9836 & \multirow{3}{*}{, 568} & \multirow{2}{*}{, 637} \\
\hline $26-34$ & 32 & 3,2059 & & \\
\hline $35-44$ & 32 & 2,9357 & & \\
\hline Total & 230 & 3,0074 & & \\
\hline
\end{tabular}

'Tüketicilerin Etnosentrizm düzeyleri eğitim durumlarına göre farklıık gösterir' şeklinde ifade edilen $\mathrm{H}_{3}$, varyans analizi ile test edilmiş ve sonuçlar Tablo 7'de gösterilmiştir. Tablo 7'deki sonuçlara bağlı olarak $\mathrm{H}_{3}$ hipotezi kabul edilmiştir. Buna göre; tüketicilerin etnosentrik düzeyleri, eğitim durumlarına göre farklıık göstermektedir.

Tablo 7: Tüketici Etnosentrizm Düzeyleri İle Eğitim Faktörlerine ilişkin Varyans Analizi Sonuçları

\begin{tabular}{|c|c|c|c|c|}
\hline & $\mathrm{N}$ & Ortalama & F-değeri & Anlamlılık \\
\hline illköğretim & 11 & 3,8449 & \multirow{4}{*}{5,250} & \multirow{4}{*}{,006 } \\
\hline Lise & 142 & 2,9180 & & \\
\hline Üniversite & 77 & 3,0527 & & \\
\hline Toplam & 230 & 3,0074 & & \\
\hline
\end{tabular}

Bu farklılığın hangi gruplar arasında olduğunu görmek için yapılan Post-Hoc testi sonuçları Tablo 8'de gösterilmiştir. Grupların varyansları homojen olmadığı için (Levene testi= 3,299 $p=, 039$ ) Tamhane ve Dunnett T3 testleri gerçekleştirilmiştir. Yapılan analizin sonuçlarına göre gruplar arası farklııkta; ilköğretim mezunlarının etnosentrik eğilimlerinin lise ve üniversite mezunlarına göre daha yüksek olmasından kaynaklandığı tespit edilmiştir. Buna göre İlköğretim mezunlarının, lise ve üniversite mezunlarına kıyasla daha etnosentrik oldukları bulgusu elde edilmiştir. Analiz sonuçları; ilköğretim ve lise arasındaki düzey farkının ilköğretim ve üniversite arasındaki düzey farkından daha büyük olduğunu göstermektedir. Türkiye'nin 4+4+4 zorunlu eğitime geçmesi ile günümüzden itibaren Lise düzeyinden daha düşük bir eğitim seviyesi olmayacağı gerçeği üzerinden, yapılan analizde Lise ve Üniversite gruplarının arasında tüketici etnosentrizm düzey farkııı olmamasına ilişkin olarak, gelecekte 'eğitim' farkı itibariyle etnosentrik eğilim farkının olmayabileceği söylenebilir.

Tablo 8: Etnosentrizm Düzeyleri Arasındaki Farkın Kaynağını Belirlemek Üzere Uygulanan Post-Hoc Testlerine i̇lişkin Sonuçlar- Eğitim Faktörü

\begin{tabular}{|c|c|c|c|c|c|c|c|}
\hline & \multirow{2}{*}{$\begin{array}{l}\text { Eğitim } \\
\text { Düzeyi } \\
\text { (I) }\end{array}$} & \multirow{2}{*}{$\begin{array}{l}\text { Eğitim } \\
\text { Düzeyi } \\
\text { (J) }\end{array}$} & \multirow[b]{2}{*}{$\begin{array}{l}\text { Ortalama Farkı } \\
\qquad(I-J)\end{array}$} & \multirow[b]{2}{*}{ Std. Hata } & \multirow[b]{2}{*}{ Anl. } & \multicolumn{2}{|c|}{ \%95 Güven Aralığı } \\
\hline & & & & & & Alt Sınır & Üst Sınır \\
\hline \multirow[t]{6}{*}{ Tamhane } & \multirow[t]{2}{*}{ İlköğretim } & Lise & ,92694 & ,16319 & ,000 & ,4948 & 1,3591 \\
\hline & & Üniversite & ,79221" & , 17886 & 001 & ,3326 & 1,2518 \\
\hline & \multirow[t]{2}{*}{ Lise } & İlköğretim &,$- 92694^{*}$ & ,16319 & 000 & $-1,3591$ &,- 4948 \\
\hline & & Üniversite &,- 13473 & ,13348 & ,678 &,- 4569 & ,1875 \\
\hline & \multirow[t]{2}{*}{ Üniversite } & İlköğretim &,$- 79221^{*}$ & ,17886 & 001 & $-1,2518$ &,- 3326 \\
\hline & & Lise & ,13473 & ,13348 & 678 &,- 1875 & ,4569 \\
\hline \multirow[t]{6}{*}{ Dunnett T3 } & \multirow[t]{2}{*}{ İlköğretim } & Lise & ,92694* & ,16319 & 000 & ,4970 & 1,3569 \\
\hline & & Üniversite & ,79221* & ,17886 & 001 & ,3342 & 1,2503 \\
\hline & \multirow[t]{2}{*}{ Lise } & Lise &,$- 92694^{*}$ & ,16319 & 000 & $-1,3569$ &,- 4970 \\
\hline & & Üniversite &,- 13473 & ,13348 & ,676 &,- 4568 &, 1873 \\
\hline & \multirow[t]{2}{*}{ Üniversite } & İlköğretim &,$- 79221^{*}$ & ,17886 & 001 & $-1,2503$ &,- 3342 \\
\hline & & Lise & ,13473 & ,13348 & ,676 &,- 1873 & ,4568 \\
\hline
\end{tabular}

Araştırma amaç ve hedefleri doğrultusunda yapılan hesaplama ve analizler ışığında araştırmanın ortaya koymak istediği; küreselleşmenin kültürel etkilerine ilişkin 3-tezi tüketici etnosentrizmi aracılığı ile aşağıdaki şekilde sınanmıştır. 
Türk tüketicilerin etnosentrik eğilim düzeyi 'orta' düzey olarak gerçekleşmiştir. Buna göre küreselleşmenin kültürel etkilerine ilişkin 3-tez, 'tüketici etnosentrizmi' faktörü ile sınanmış ve elde edilen sonuçlara bağlı olarak 'hibritleşme tezi'nin olası en doğru tez olabileceği bulgusu elde edilmiştir. Bu bulgu Tablo 9'da özet halinde sunulmuştur.

Tablo 9: Küreselleşmenin Kültürel Etkilerine İlişkin Tezlerin Tüketici Etnosentrizmi İle Sınanması

\begin{tabular}{|c|c|c|c|}
\hline $\begin{array}{c}\text { Küreselleşmenin Kültürel } \\
\text { Etkilerine İlişkin Tezler }\end{array}$ & $\begin{array}{c}\text { Araştırma } \\
\text { Varsayımları }\end{array}$ & $\begin{array}{c}\text { TürkTüketicilerin } \\
\text { Etnosentrik Eğilim } \\
\text { Düzeyi }\end{array}$ & $\begin{array}{c}\text { Sınama } \\
\text { Sonucu }\end{array}$ \\
\hline Homojenlik Tezi & $\begin{array}{c}\text { Türk Tüketicisinin Etnosentrik } \\
\text { Düzeyi Düşük }\end{array}$ & Orta & Desteklenmedi \\
\hline Kutuplaşma Tezi & $\begin{array}{c}\text { Türk Tüketicisinin Etnosentrik } \\
\text { Düzeyi Yüksek }\end{array}$ & Orta & Desteklenmedi \\
\hline Hibritleşme Tezi & $\begin{array}{c}\text { Türk Tüketicisinin Etnosentrik } \\
\text { Düzeyi Orta }\end{array}$ & Orta & Desteklendi \\
\hline
\end{tabular}

\section{SONUÇ}

Mevcut araştırma ile küreselleşmenin kültürel etkilerine ilişkin sosyoloji yazınında yer alan üç tez, tüketici etnosentrizmi aracılığıyla sınanmış ve cinsiyet, yaş, eğitim faktörlerine göre tükecilerin etnosentrik eğilimleri incelenmiştir. Araştırmada kullanılan 17-birimlik CATSCALE ölçeği ile yapılan ölçüm güvenilir bulunmuştur. Araştırma 230 tüketici üzerinde, yüz yüze anket şeklinde yapılmıştır. Araştırma sonuçları aşağıda özetlenmiştir. Tüketici etnosentrizm düzeyi yaş ve cinsiyet faktörlerine göre farklıık göstermemekte, ancak eğitim faktörüne göre farklılık göstermektedir. İlköğretim ile Lise ve Illköğretim ile Üniversite grupları arasında anlamlı fark elde edilmiştir. Türk tüketicilerin etnosentrik eğilim düzeyi 'orta' düzeyde gerçekleşmiştir. Bu bulgu, küreselleşmenin kültürel etkilerine ilişkin üç olası tez olan homojenleşme, kutuplaşma ve hibritleşme tezlerinde hibritleşme tezini desteklemiştir. Küreselleșme gerek sosyal, gerek ekonomik ve gerekse kültürel etki gücüne sahip olan, günümüz ve gelecekte yaşamın bir çok alanını yapılandırma özelliğinden dolayı etkisi gün geçtikçe artan bir konu olma özelliği taşımaktadır. Bu gerçekle küreselleşme ve yarattığı sonuçlar üzerinde yapılacak araştırmalar, ekonomilerdeki aktörlerin geleceğe ilişkin yol haritalarını oluşturmalarına temel olacağı aşikardır. Bu anlamda araştırma sonuçlarının gerek pazarlama ve tüketici davranışları, gerekse sosyoloji ana bilim dallarına önemli bulgular verdiği söylenebilir. Araştırma zaman ve maliyet kısıtları dolayısıyla 230 kişi üzerinden veri toplanarak yapılmıştır. Araştırmaya katılma gönüllülük ilkesi ile olduğundan, bulgular bölümünde görüldüğü üzere, araştırmaya daha çok genç yaşta olanların daha istekli oldukları, ileri yaşta olanların ise araştırmaya çok az katılım gösterdikleri görülmektedir. Bu durum 'yaş' değişkenine ilişkin gruplar arası farklıığın olmadığı sonucunu yaratmış olabileceği okuyucunun dikkatlerine sunulmuştur. Bundan sonraki araştırmaların daha geniş örnek hacmi ile yapılması önerilir.

\section{KAYNAKLAR}

Akın, M., Çiçek, R., Gürbüz, E., İnal, E.M. (2009). Tüketici etnosentrizmi ve davranış niyetleri arasındaki farklılığın belirlenmesinde Cetscale ölçeği. Ege Akademik Bakış Dergisi, 9 (2), pp 489-512.

Altıntaş, M. H. ve Tokol, T. (2007). Cultural openness and consumer ethnocentrism: An empiricalanalysis of Turkish consumers. Marketing Intelligence and Planning, 25(4), pp.308-325.

Arı, E.S., Madran, C. (2011). Satın alma kararlarında tüketici etnosentrizmi ve menşe ülke etkisinin rolü. Marmara Üniversitesi Sosyal Bilimler Enstitüsü Öneri Dergisi, 9(35), pp.15-33.

Armağan, E. A., Gürsoy, Ö. (2011). Satın alma kararlarında tüketici etnosentrizmi ve menşe ülke etkisinin cetscale ölçeği ile değerlendirilmesi. Organizasyon ve Yönetim Bilimleri Dergisi, Cilt 3, Sayı 2, pp. 67-77

Asil, H., Kaya, I. (2013). Türk tüketicilerin etnosentrik eğilimlerinin belirlenmesi üzerine bir araştırma. İstanbul Üniversitesi İşletme Fakültesi Dergisi, 42(1), pp. 113-132.

Balabanis, G., Diamantopoulıs, A. (2004). Domestic country bias, contry-of-origin effects, and consumer ethnocentrism: A multidimensional unfolding approach, Academy of Marketing ScienceJournal, 32(1), pp. 80-95.

Bearden, W.O., Hardesty, D.M., Rose, R.L.. (2001). Consumer self-confidence: Refinements in conceptualization and measurement. Journal of Consumer Research 28(1) (June), pp.121-134. 
Cateora, p. (2000). International marketing, Irwin iç. Saffu, K. Ve Walker, J.H. (2005). An assessment of the consumer ethnocentric scale (CETSCALE) in an advanced and transitional country: The case of Canada and Russia, International Journal of Management, 22(4), 556-571.

Çilingir, Z. (2014). Tüketici etnik kökenciliği ğğilimi ölçeği (Cetscale): İstanbul ili tüketicileri üzerine bir pilot qraştırma. Uluslararası İktisadi ve İdari İncelemeler Dergisi, 13(13), pp. 209-232.

Giddens, A. (1998). Modernliğin sonuçları, Ayrıntı Yayınları, İstanbul.

Hannerz, U. (1998). Çevre kültür senaryoları. Küreselleşme ve Dünya Sistemi, Çev. G. Seçkin ve H.Yolsal, Bilim ve Sanat Yayınları, Ankara.

Harvey, U. (1992), The condition of postmodernity. Blackwell, Oxford. İç. Holton, R. (2013), Küreselleşmenin Kültürel Sonuçları, Sosyoloji Konferansları, 47(1): 59-75.

Holton, R. (2013), Küreselleşmenin kültürel sonuçları. Sosyoloji Konferansları, 47(1), pp. 59-75.

İşler, D. B. (2012). Tüketici entrosentrizmi ve menşe ülke etkisi ekseninde satın alma kararlarındaki rolü: CETSCALE ölçeği ile bir uygulama. Abant İzzet Baysal Üniversitesi Sosyal Bilimler Enstitüsü Dergisi, 26(26), pp. 93-122.

Kaynak, E., Kara, A. (2000). Consumer perceptions of foreign products: An analysis of product-country images and ethnocentrism. European Journal of Marketing, 36(7/8), pp.928-949.

Keyman, F. (1998). Globalleşme ve öteki sorunu: Postmodernizm, feminizml, oryantalizm. Küreselleşme, Sivil Toplum ve İslam, Vadi Yayınları, Ankara. İç. İçli, G. (2001), "Küreselleşme ve Kültür”, C.Ü. Sosyal Bilimler Dergisi, Aralık 25(2): 163-172.

Klein, J.G.,Ettenson, R., Morris, M.D. (1998). The animosity model of foreign product purchase: An empirical test in the People's Republic of China. Journal of Marketing, 62(1), pp. 89-100.

McNeill, W. (1986), Polyethnicity and national unity in world history. University of Chicago Press. İç.Holton, R. (2013), Küreselleşmenin Kültürel Sonuçları, Sosyoloji Konferansları, 47(1): 59-75.

Netemeyer, R.G.,Durvasula, S., Lichtenstein, D.R. (1991). A cross-national assessment of the reliability and validity of the CETSCALE. Journal of Marketing Research, 28(8), pp. 320-327.

Örs, H., Yılmaz, V., Doğan, M. (2016). Effect of consumer ethnocentrism on perceived service quality and examination of this contex by cultural relativity and demographic factors: An empirical Study. Journal of Management, Marketing and Logistics, pp. 14-27.

Robertson, R. ( 1998). Toplum kuramı, kültürel görecelik ve küresellik sorunu. Küreselleşme ve Dünya Sistemi, Çev. G. Seçkin ve H.Yolsal, Bilim ve Sanat Yayınları, Ankara.

Shankarmahesh, M. N. (2006). Consumer ethnosentrism: An integrative review of its antecedents and consequences. International Marketing Review, 23(2), pp. 146-172.

Shimp, T.A., Sharma, S. (1987). Consumer ethnocentrism: Consruction and validation of the CETSCALE. Journal of Marketing Research, 24(8), pp. 280-289.

Turgut, B. A. (2010). Tüketici etnosentrizminin satınalma davranışlarına etkisi: Hizmet sektöründe bir uygulama. Yayınlanmamış Yüksek Lisans Tezi, Balıkesir Üniversitesi, Sosyal Bilimler Enstitüsü.

Uyar, K., Dursun, Y. (2015). Farkli ürün kategorilerinde yabanci markalama ve tüketici etnosentrizmi. Atatürk Üniversitesi Sosyal Bilimler Enstitüsü Dergisi, 19 (2), pp.363-382

Wang, C. I., Chen, Z.Y. (2004). Consumer ethnocentrism and willingness to buy domestic products in a developing country setting testing moderating effects. Journal of consumer Marketing, 21(6), 391-400.

Yapraklı, T. Ş., Keser, E. (2013). Tüketici etnosentrizmi: Beyaz eşya ve içecek sektörlerinde karşılaştırmalı bir saha araştırması. Sosyal Ekonomik Araştırmalar Dergisi, (25), pp. 385-420. 